\title{
The Psychosocial Development of the Seminarians and the Positive Affirmation Skills Intervention (PASI)
}

\author{
Sister Gracia T. Gegajo ${ }^{1}$ \\ ${ }^{1}$ University of Santo Tomas, Manila Philippines \\ Received: May 28, 2021 \\ Received in Revised: June 24, 2021 \\ Accepted: July 13, 2021
}

\begin{abstract}
This study aimed to develop the Positive Affirmation Skills Intervention and determine its efficacy on the Psychosocial Development of the Seminarians. The present study uses Advanced Mixed Method Design, which integrates quantitative and qualitative data from human problems, stories, and challenges. Researchers gather and evaluate qualitative data first, then create something helpful (Phase 2), such a new variable or intervention (experiment) (Quantitative). The result of the study shows positive Affirmation Skills Intervention (PASI) program proves to be an efficacious tool for enhancing the level of the psychosocial development attributes of the seminarians. Results showed no significant difference between the pretest scores of the experimental group and the control group.
\end{abstract}

Keywords: PASI, Seminarians, Psychosocial Development

\section{Introduction}

Being engaged in these past years in the different seminaries, the researcher was confronted to the call of accountability and involvement in the formation of the seminarians who will become the future priests of our church. This is a concern very near to the heart of the researcher since it is in integration of the psycho social life of a seminarian that forms his core being and brings into maturity his vocation. Seminary formation is very vital since these seminarians will be the prospective leaders that will shepherd the humankind towards a holy and integrated Christ-like life.

Avouching the Program for Priestly Formation will reinforce the human and formative process and adjunct in the advancement of seminarian's discernment for their human, psycho social and spiritual maturity that will serve as a channel to the gracious presence of Christ in his pastoral ministry.

This study was thought to contribute to the development and enhancement of the psychosocial skills, assertive communication, self-concept, decision making, self-management, sense of trust to others, problem solving and interpersonal relationship more effectively on the personhood of a seminarian who is preparing to be a future priest. A process of maturation of personality traits, dimensions and behavior focusing on the "person development" is the first interest of the seminarian who underwent this positive affirmation skills intervention. The researcher felt the urgent needs for ways and approaches that can be of help to these seminarians to enhance their personality dispositions, traits, behaviors, cognitions, emotions and intellectual capacity in the development of their own, interpersonal and cultural experiences in the seminary formation.

Findings of this study can be of benefit to the Formators, the seminary formation team, vocation directors, rectors, administrators, guidance counselors, psychologists and psychotherapists of a diocesan and religious seminary who were the main evaluators in the assessment of the psychosocial, emotional, spiritual maturity of the seminarians. With the essential knowledge that will be imparted by this study on the effect of the positive affirmation skills intervention 
on the psychosocial development of the seminarians, these persons may have a deep and more functional information of the strength and changing disposition of the positive affirmation skills enhancement on the seminarians psychosocial behaviors and process of maturity level. Therefore, the said study facilitated and aided the course for this team of seminary personnel to update, make use and train to achieve for the goal of the well-being and betterment of the process of social skills integration, the interpersonal relationships management as a tool in the development and human formation to help the seminarians achieve their sense of self-esteem and concept.

In this study the researcher sought to develop the Positive Affirmation Skills Intervention and determine its efficacy on the Psychosocial Development of the Seminarians. For the first phase of the study, the researcher specifically answered what is the composition of Positive Affirmation Skills Intervention (PASI) and what are the pre-test and post-test psychosocial development mean scores and standard deviation values of the experimental and control group as measured by The Modified Erikson Psychosocial Stage Inventory (MEPSI).

\section{Hypotheses}

H0: There is no significant difference between the pre-test and post-test psychosocial development mean scores of the seminarians when grouped according to experimental group and control group.

H1: There is no significant difference between the post-test psychosocial development mean scores of the experimental and control group

\section{Methods}

The present study is a program development endeavor that makes use of the Advanced Mixed Method Design of John Creswell. This is an emerging research approach in the social and health sciences that involves combining both statistical trend (quantitative) and human problems, stories (qualitative data) in a single study or in multiple phases of a study. It has 4 Key Features: 1) Collecting and Analyzing qualitative and quantitative data (open and close ended) in response to research questions. 2) Using rigorous qualitative and quantitative methods. 3) Combining or integrating quantitative and qualitative data using a specific type of mixed method design and 4) Framing the mixed method design with a broader framework (experiment).

The core assumption of this method is that combined use of quantitative and qualitative approaches provides better understanding of research problems than either approach alone. In Advanced Mixed Method design, the researcher used a basic design which is the Exploratory Sequential Design (with the use of ethnography) and put a more feature design that is an added framework (experimental).

This Exploratory Sequential Design (with the use of ethnography) starts with a qualitative data (Phase 1) collection and analysis and the researcher develop something that can be used (Phase 2), which is the Instrument (new variable) or intervention activities (experiment); the researcher administer and test it up and have the interpretation (Quantitative). This is to explore first before building to a quantitative phase.

This basic designs are part of a large framework and by working with this larger framework, the researcher ask where are we collecting quantitative and qualitative data and where is she bringing these two data bases together. This is exploring the basic designs and adding with the use of a framework. 
This current study focuses on two aspects: Phase 1 focuses on the program development of Positive Affirmation Skills Intervention (PASI), while phase 2 focuses on the examination and implementability of the intervention on the Psychosocial Development of the seminarians

\section{Result and Discussion}

\section{Phase 1}

\section{Focus Group Discussion}

The seminarians were divided into three groups for the focus group discussion in order for the researcher to get the seminarians' personal views and perceptions about their day to day life in the seminary with regards to their issues in their psychosocial development. All participants were very cooperative, enthusiastic and they expressed their personal views without any hesitation thus making their views valuable and meaningful. The focus group discussion indicated that with regards to their adjustments, difficulties and struggles in their stay in the seminary, all the three groups comprised of fifteen seminarians per group answered in majority that seminary culture like schedule and demands of formation are for them a big struggle in their adjustment to seminary life. The transition from the life outside, being a person who manages his own life and schedule and inside the seminary wherein the seminarians find themselves bounded by the schedule is not easy.

The socialization factor which demands adjustment on their part since they have to have interpersonal relationships with their co-seminarians and formators.

Another factor is the problem in social communications and behavioral issues. Next is the selfconcept and self-esteem which is a concern in the journey of a seminarian that challenges them to face their own personal and social life in the seminary. Other concerns of adjustments, difficulties, struggles and academics are the responsibilities given to them in their stay in the seminary.

With regards to the upbringing and influence in their behavior pattern wherein they encounter challenges and difficulties in "adapting" the culture of seminary life, the seminarians shared five things which they viewed important and these are: openness, attitude and behavior, decision-making, responsibility, principles and philosophy in life.

Thoughts that often come to mind to the seminarians are the thoughts with regards to their vocation, future commitment, discernment, decision-making, meaning of life and existence and of responsibilities. Almost all of the seminarians in the three groups respectively asked themselves. For the emotional, behavioral, psychosocial, psychospiritual and interpersonal challenges encountered in the seminary.

Responses on how they were able to cope with these challenges, issues and concerns in the seminary were: thru Spiritual direction, somebody to guide and listen to them; self-awareness, positive thoughts, self-talk, workout oneself, insights, maturity of the person and decisionmaking.

These personal views and reactions of the seminarians as focus group participants to their adjustments, difficulties and struggles in their stay in the seminary with their challenges in their behavioral, emotional, psychosocial and interpersonal issues encountered in the seminary, so with their ability on how to cope with these issues was their great concern.

The seminarians' lack of positive coping styles and psychosocial skills were some of the causes of their problems, conflicts in dealing with their co-seminarians and formators. They were not trained to exercise positive affirmation and social skills in order that their life situations in the 
seminary can be improved and they can be helped mentally, behaviorally, intellectually, psychologically and socially in their future ministry and life as Christ's servants and followers.

\section{Interview with the Seminarians}

For the interview, the researcher interviewed thirty seminarians; this is to find out the main issues and concerns of the seminarians with regards to their psychosocial development in the seminary

For the interview with the seminarians, 28 guide questions were asked to the seminarians, these 28 questions were divided into six areas: Motivation (3), Emotions (5), Thoughts (5), Images (2), Behavior (6) and Social Relationships (7). Responses were:

In Motivation, difficulty in opening up, culture and fear of rejection are the main points that came up in their answers in their social relationships with co-seminarians. The areas that they find hard to perform in the seminary are their social relationships in dealing with others, their intellectual capacity and the schedule in the seminary. Most of them answered affirmatively on whether they experience struggle in dealing with oneself and with their co-seminarians; personal issues and negative self-concept emerged as the reason for this struggle.

On Emotions, most of the seminarians admitted that sometimes they are incapable to experience pleasure and happiness in relation with their co-seminarians and some of the seminarians answered positively most of the time in this area. Majority of them strongly feel that seminary life is difficult. There are times that they also experience anger and other negative emotions with themselves and mentioned that other people are hindrance for them. Certain situations that make them irritated are the violation of their own privacy and the experience that they usually do in the seminary that makes them feel negative are those things that do not correspond to what is good.

On their Thoughts, negative thoughts are more frequent in their years of college and they even notice situations and events that make them more negative in the seminary. Most of the seminarians also said that sometimes these negative situations and experiences in the seminary come into their mind more readily than the positive thoughts like being forgiven, appreciated and loved and sometimes they are convinced that they can do nothing about their behaviors since they think that 'they are already like that" and "unsociable".

With regards to the Images, they currently "picture" the feelings of being uncomfortable and irritable when they are in conflict with their co- seminarians and experience to be in great difficulty coming out of themselves and they do not know where to start.

With matters of Behavior, they rank the spiritual, attitudinal and academics as their activities that are difficult for them to perform, quoting that many times they find it difficult for themselves. With this experience of conflict with their co-seminarians, they also find it annoying especially when they do not ask pardon and wherein insult comes in and hinders them.

They deliberately avoid talking with their co-seminarians when they come to realize that they hurt the person since they want them to reflect and keep silent in order to let them think of what they have done.

They admitted that they needed and wanted to talk to their formators but do not know how to say it. They also acknowledge that sometimes they try to escape in the seminary or in some of its events but said that they have to manage to face and handle certain difficult situations in their seminary life. 
In their Social Relationships, they observed that sometimes they are not interested to interact with their co-seminarians and with their formators. In refusing to the requests asked from them, they tell them or let them know; others try to resist them. They acknowledge that there are conflicts in their seminary life that bothers them, have some resentment and unable to express their own sentiments. Sometimes they feel bad of themselves and others; they feel and think that their co-seminarians do not understand them in what they are going through.

\section{Survey with the Seminarians}

In the survey with the seminarians, the researcher distributed the survey questionnaires to the fifty-six seminarians wherein all of them answered the given questionnaire. The survey questionnaire was composed of thirty questions and divided into ten questions for every area on their relationship with oneself, with formators and others.

The survey questionnaire was answered by the seminarians by checking the yes or no column. Most of the answers that are highlighted in the concerns of the seminarians were summarized and results showed that majority of the seminarians in terms of their relationship with oneself are: they doubt themselves and others, they cannot express oneself without hesitation and selfconfidence is difficult.

In view with their relationship to their formators, the seminarians are in great difficulty opening up and talking some of their concerns to their formators; they cannot easily discuss things with their formators since they are not at ease with them.

With their relationship to others, they admitted that they doubt them and they find it difficult to discuss things with their fellow seminarians.

\section{Interview with the Bishop}

The Bishop of the diocese was very warm and accommodating in his interview in spite of his full and hectic schedule of meetings, pastoral visit, confirmations, etc. in his ministry as the father of the diocese. He is very much concerned of the spiritual, emotional, psychosocial, intellectual and human growth of the seminarians since he is the first person responsible for the formation of the seminarians who in the future will be the priests in his local church who will guide the Christian community, proclaim God's word and celebrate the mercy and love of Christ.

They need to be educated to love the truth, to be loyal, to respect every person, to have that sense of justice, to be true to their word, to be genuinely compassionate, to be men of integrity and especially to be balanced in judgement and behavior. (Decree on Priestly Formation, Second Vatican Ecumenical Council Optatam Totius, 11).

\section{Interview with the Formators}

The challenges/ difficulties in terms of the seminarian's psychosocial development are their electronic gadgets; as mentioned by a formator: "they are distracted by the electronic gadgets that they have and also the dysfunctional families".

Challenges in terms of trust with co-seminarians is bullying, there are those who have strong personality, they don't trust their co-seminarians; they have their groups and there is the seminary culture which is the "bansag" ("names"). There is no seniority, no hostility but some have strong personality.

In terms of the difficulty being "expected" and "demanded" to be a person of what one has to become and as a person wherein the society expects to become: they find this difficult since other seminarians are not ready to accept responsibilities, they are hesitant on this. 


\section{Interview with the Professors}

The challenges and difficulties in terms of psychosocial development as quoted by a professor is "their relationship with the opposite sex, they are shy, they easily become their girlfriend"; "maturity logs since it is the world of male persons"; "all are male, the challenge is if you are effeminate, there will be reactions and they will tease you".

In terms of trust with co-seminarians: "trust with co-seminarian is high, since they are together in the so called "crime".

With their formators: "This depends on the priest" because of their role played; others are not authoritative but "comrade".

With other persons (professors/collaborators): "they are far from them" because their relationship with them is very functional, not in the aspect of formation; they will not go deeper since it is not like formators, they are just like educators and in the classroom setting."

With regards to oneself: "Pinakama aksyon" ("this is full of action"), "difficult to discern; if the seminarian confronts himself, "maraming bumabagabag sa sarili" ("many things bother him"), "active sa formators" ("active to the formators").

About their fears, anxieties and insecurities in the seminary: "their fear is that they will be sent out because of a stupid thing done"; it is used against them to discipline. In insecurities: "if you are weak", example in sexuality, intellectual capacity or "thrifty", you are peer pressured and you are targeted where you are weak."

Challenges in their decision making, with regard to their vocation, is considered with the influence of parish activities/ groups like being a sacristan or they are a product of youth ministry.

In their task performance and handling problems: they have this problem in communication skills, "they find it hard to assert, those who are a bit senior they can assert", "it is an adjustment period", "they need to be pushed since they are shy, and those who are well-off are confident, noisy and vocal".

The frustrations that are manifested in their behaviors in relation to their interpersonal and their own personal relationship: "The priests and formators"; because of their ideal and real situations, "issues", "gossips" "they are been talked to".

In the achievement of their goal: they achieve their goal through group effort, "peer" is very strong, support group is very important"; ("ka-batch") batch mate, and "friendship", "either negative or positive".

Problems in terms of their identity (expression of ideas, opinions,, etc.), since they are in their adolescence, there is that immaturity; " you will be in crisis since they will fool you". For the self-esteem (thoughts and feeling one's own worth), bonding with the group is important for them, it boost their self-esteem because of friendship.

In terms of their commitment, "they are not serious with this because they don't see its importance, they evade commitment and are immature; they still play with this; it is still on process, working with it."

With regards to their motivation, "they can do it and forced to do it if they want the result of the output is what they want". Also the spiritual life and poverty causes' motivation because of the pressure from the parents. "They can have elegant clothes but cannot afford to pay for their school". 
About communication skills: their problem with this are their background, "ung pinagmulan" ("where they came from") and along the road it is where you can see their improvement and efficiency"; their socialization is developed.

The emotional experiences/ awareness that they went through inside the seminary are: "Ang pilitin sila na sumunod sa structure" ("to force them to follow the structure"), detachment is not a big issue; self-control and discipline is an issue, ("you have to do things in a way that must be done even though you are not yet like that").

They underwent process, "during mealtime, if you don't want the food you will still eat it, if you have no study habit you will establish it and if it is time for prayer, you have to pray; this is the system given by the seminary.

The difficulty of finding oneself being "expected' and "demanded" to be person of what one has to become and as the person society expects to become is true for the seminarians. "People expect and demand from you since you are a seminarian". Even the parish priest they have their "expectation"; discipline is included. If family support lacks on the part of the seminarian the seminarian will be in difficulty. ("In the seminary the seminarians are taught to "act like a priest").

\section{Pilot Study}

Table 1. Pretest and Posttest Psychosocial Development Mean Scores and Standard Deviation Values and Wilcoxon Signed Rank Test of the Pilot Study $(\mathrm{N}=13)$

\begin{tabular}{|c|c|c|c|c|c|c|c|}
\hline Scale interpretation & $\begin{array}{c}\text { Pretest M } \\
(\text { SD) }\end{array}$ & VI & $\begin{array}{c}\text { Post test } \\
\mathbf{M}(\text { SD) }\end{array}$ & VI & $\begin{array}{c}\text { Sum of } \\
\text { Ranks }\end{array}$ & $\begin{array}{c}\text { P } \\
\text { value }\end{array}$ & $\begin{array}{c}\text { Sig. (2- } \\
\text { tailed) }\end{array}$ \\
\hline $\begin{array}{c}\text { Trust-Mistrust } \\
\text { Significant }\end{array}$ & $3,15(.52)$ & Low & $3.35(.41)$ & Low & 14.50 & .099 & Not \\
\hline $\begin{array}{c}\text { Autonomy-Shame } \\
\text { and Doubt } \\
\text { Significant }\end{array}$ & $3.24(59)$ & Low & $3.48(41)$ & Low & 6.00 & .050 & Not \\
\hline $\begin{array}{c}\text { Initiative-Guilt } \\
\text { Significant }\end{array}$ & $3.15(.55)$ & Low & $3.39(.39)$ & Low & 19.50 & .228 & Not \\
\hline $\begin{array}{c}\text { Industry-Inferiority } \\
\text { Significan }\end{array}$ & $3.47(.55)$ & Low & $3.55(.57)$ & Low & 32.00 & .575 & Not \\
\hline $\begin{array}{c}\text { Identity-Role } \\
\text { Confusion } \\
\text { Significant }\end{array}$ & $3.44(.47)$ & Low & $3.42(.41)$ & Low & 26.50 & .919 & Not \\
\hline $\begin{array}{c}\text { Intimacy-Isolation } \\
\text { Significant }\end{array}$ & $3.28(.52)$ & Low & $3.36(.47)$ & Low & 22.50 & .609 & Not \\
\hline $\begin{array}{c}\text { Generativity- } \\
\text { Stagnation - } \\
\text { Stagnation } \\
\text { Significant }\end{array}$ & $3.57(.42)$ & Low & $3.50(.45)$ & Low & 26.50 & .562 & Not \\
\hline $\begin{array}{c}\text { Ego Identity-Despair } \\
\text {-Despair Significant }\end{array}$ & $3.42(.52)$ & Low & $3.53(.41)$ & Low & 15.00 & .673 & Not \\
\hline MEPSI Significant & $3.31(.44)$ & Low & $3.38(.30)$ & Low & 21.50 & .539 & Not \\
\hline
\end{tabular}

Legend: $1-2=$ Low score (negative attributes; (if dichotomy low, high) $<3.9=$ low and $>4=$ high;

4-5 =high (positive attributes); MEPSI=Modified Erikson Psychosocial Stage Inventory; $\mathrm{VI}=$ Verbal Interpretation

Note: Significant if $\mathrm{p}<0.05$

Copyright $\odot$ 2021, Journal of Asian Multicultural Research for Social Sciences Study, Under the license CC BY-SA 4.0 
W stat $=3.5 \quad$ Wcrit $=17$

It can be seen from Table 3 the mean scores and the standard deviation values of the pretest and posttest of the Pilot Study Group as measured by MEPSI. The Mean measures the central tendency or position of scores. It may also refer to the average. The Standard Deviation values show the degree to which the scores vary from the mean.

The participants in Table 1 reported a low level of psychosocial development attributes based on the pre-test. This showed homogeneity of the research participants before the administration of the Positive Affirmation Skills Intervention (PASI) and implied that they have the same level of the psychosocial development attributes. The pre-test overall scores of MEPSI of the participants showed a low level (Mean=3.31, SD=.44) of psychosocial development attributes. This meant that the participants demonstrated a predominance of negative attributes prior to the administration of the program. It also confirms that the psychosocial attributes of the seminarians in terms of the Scale of Trust $(M=3.15 \mathrm{SD}=.52)$, Autonomy $(\mathrm{M}=3.24 \mathrm{SD}=.59)$, Initiative $(\mathrm{M}=3.15 \mathrm{SD}=.55)$, Industry $(\mathrm{M}=3.47 \mathrm{SD}=.55)$, Identity $(\mathrm{M}=3.44 \mathrm{SD}=.47)$, Intimacy (M-3.28 SD=52), Generativity $(\mathrm{M}=3.57 \mathrm{SD}=.43)$ and Ego Identity $(\mathrm{M}=3.42 \mathrm{SD}=.52)$ are low and are negatively predominant.

This signifies that before the administration of PASI the level of the eight subscales of the psychosocial development of the participants of the pilot study group are low. This means that their sense of trust, self-esteem, ability of assertion and interaction with their co-seminarians are also low. This is also true with their self-confidence, industriousness, their ability to explore their personal skills and initiatives which reflected as negatively predominant. On the other hand, even their level of their sense of reintegration, ability to share oneself more intimately to others, their sense of commitment, integrity and productivity in work are low and are also predominantly negative.

It is also presented in Table 1 the posttest mean scores and the Standard Deviation values of the pilot study group participants which reported a low level of psychosocial development attributes after PASI was administered but apparently increased in their scores as compared to their pre-test score. However, the Identity (Mean=3.42, SD=.41) and the Generativity subscale score (Mean= 3.50, $\mathrm{SD}=.45$ ) was lower in the posttest which signifies that their sense of reintegration and productivity in work are still low.

The other posttest scores of the participants of the Pilot Study Group signify that there was an increase in the level of the psychosocial development attributes of the seminarians in terms of their sense of trust $(M=3.34 \mathrm{SD}=.41)$, self-esteem and assertion in the group $(\mathrm{M}=3.48 \mathrm{SD}=.43)$. So with the posttest scores of the pilot study group in terms of interaction with co-seminarians, their ability to explore their personal skills and in their initiatives $(\mathrm{M}=3.39 \mathrm{SD}=.39)$; their selfconfidence and industriousness $(\mathrm{M}=3.55 \mathrm{SD}=.57)$. It revealed there was an increase in the level of its subscale. Moreover, an increase in the level of the posttest mean scores in the attributes of the subscale of intimacy and commitment $(M=3.36 \mathrm{SD}=.47)$, integrity $(\mathrm{M}=3.53$ $\mathrm{SD}=.41)$ and the overall MEPSI $(\mathrm{M}=3.38 \mathrm{SD}=.30)$ which can also be seen and which signified that the level of the psychosocial development of the pilot study group who received the intervention of PASI has shown an increase in their scores.

This means that the Positive Affirmation Skills Intervention program enhanced the Psychosocial Development attributes of the seminarians in the Pilot Study Group. This affirms Neyer \& Lehmart (2007) eight year longitudinal study across young adulthood of relationships in Personality development and that of Parker et al. (2012), personality and relationship quality during transition from high school to early adulthood wherein they stated that "increases in the quality of relationships with friends were found to go hand in hand with increases in emotional stability, agreeableness and extraversion. Furthermore, Zimmermann \& Neyer (2013)

Copyright $\odot$ 2021, Journal of Asian Multicultural Research for Social Sciences Study, Under the license CC BY-SA 4.0 
mentioned that young adults, peer relationships were found to explain differential personality development of sojourners and control students.

This also confirms Cohen's description of positive emotion that helps to improve well-being and life reducing psychological wounds and reactivity. It encourages pursuit of opportunities, creates positive cycles and promotes success. A focus on our strength that urges us to move elicited towards accomplishment of dreams, openness of new ideas and plans eliciting resources of our strengths that opens us up as mentioned by (Goleman, 2013).

The Wilcoxon Signed Rank test is used to determine if the pretest scores significantly differ from the posttest scores. It is a non-parametric test and it is used because of the small number of participants. Table 1 also presented the Wilcoxon signed rank test result of the variables. It showed that in two weeks, once daily, Positive Affirmation Skills Intervention program did not have a statistically significant change in the seven subscales of the psychosocial development of the pilot study participants. However in one subscale which is the Autonomy-Shame and Doubt $(\mathrm{p}=.050)$ it showed a significant difference in the pretest and the posttest scores. This indicated that the PASI program statistically elicited significant change in the psychosocial development subscale on self-esteem and the ability of assertion in the pilot study group.

The Wilcoxon Statistical value is 3.5 and is lesser than the Wilcoxon Critical value of 17 which is greater and this means that there is a significant difference between the pretest and posttest of the pilot study group, therefore signifying an increase in the psychosocial development attributes of the pilot group after the administration of PASI.

This affirms Epson et al. (2005) study on positive affirmations as having positive effects, subsequent behavior and promotes acceptance, thus, improving physical and mental health which is a major area in focusing towards making one's life better. Moreover, Kang et al., (2015) validated in their study the self-affirmation as a help to level the playing field and effectively reduce the power differences. She said that anyone has the potential to do really well. It is how one responds under pressure that makes a difference. This Self-affirmation neutralizes threats and boosts confidence and performance, changing one's health and psychosocial behavior.

\section{Expert Evaluation}

The Positive Affirmation Skills Intervention was evaluated by a research team composed of a registered psychologist, a registered guidance counselor, a registered sociologist and religious, a former rector of the seminary who is an executive secretary of Catholic Bishops Conference of the Philippines (CBCP) Commission on Seminarians and a recent formator.

The evaluation of the modules was done with the criteria and guidelines wherein the evaluators checked the relevant boxes with the choices they made with the rate of Fair, Good, Very Good and Excellent and on the last part of the evaluation they need to give their comments and suggestions.

Table 2. Summary of the Expert's Evaluation of Positive Affirmation Skills Intervention (PASI) Program

\begin{tabular}{|l|l|c|c|c|}
\hline No & \multicolumn{1}{|c|}{ Excelent } & Fair & Good & Very Good \\
\hline 1. & Objectives of the Session & 3 & & 1 \\
\hline 2. & Practical Tools for Intervention & 2 & & 2 \\
\hline 3. & Duration of the Intervention & 1 & 1 & 2 \\
\hline 4. & Theoretical Base/ Concept of the Intervention & 2 & 1 & 1 \\
\hline 5. & No. of Modules and Sessions & 2 & & 2 \\
\hline 6. & Structure of Intervention Program & 3 & 1 & \\
\hline
\end{tabular}

Copyright (C) 2021, Journal of Asian Multicultural Research for Social Sciences Study, Under the license CC BY-SA 4.0 


\begin{tabular}{|l|l|l|l|l|}
\hline 7. & Efficacy of the Program for the Seminarians & 3 & & 1 \\
\hline 8. & Ethical Consideration & 3 & & 1 \\
\hline 9. & Relevance of the Intervention Program & 3 & & 1 \\
\hline
\end{tabular}

Phase 2

Table 3. Pretest and Posttest Psychosocial Development Mean Scores and Standard Deviation Values of the Experimental and Control group

\begin{tabular}{|c|c|c|c|c|c|c|c|c|c|c|c|c|}
\hline \multirow[t]{3}{*}{ MEPSI SUBSCALE } & \multicolumn{6}{|c|}{$\begin{array}{l}\text { EXPERIMENTAL GROUP } \\
(n=27)\end{array}$} & \multicolumn{6}{|c|}{ CONTROL GROUP $(n=26)$} \\
\hline & \multicolumn{3}{|c|}{ Pretest } & \multicolumn{3}{|c|}{ Posttest } & \multicolumn{3}{|c|}{ Pretest } & \multicolumn{3}{|c|}{ Posttest } \\
\hline & $\mathbf{M}$ & SD & VI & $\mathbf{M}$ & SD & VI & $\mathbf{M}$ & SD & $\begin{array}{l}\mathbf{V} \\
\mathbf{I}\end{array}$ & $\mathbf{M}$ & SD & VI \\
\hline Trust-Mistrust & 3.16 & .45 & $\mathrm{~L}$ & 3.42 & .39 & $\mathrm{~L}$ & 3.16 & .47 & $\mathrm{~L}$ & 2.93 & .51 & $\mathrm{~L}$ \\
\hline $\begin{array}{l}\text { Autonomy Shame and } \\
\text { Doubt }\end{array}$ & 3.43 & .43 & $\mathrm{~L}$ & 3.63 & .36 & $\mathrm{~L}$ & 3.22 & .51 & $\mathrm{~L}$ & 3.20 & .54 & $\mathrm{~L}$ \\
\hline Initiative-Guilt & 3.14 & .46 & $\mathrm{~L}$ & 3.50 & .35 & $\mathrm{~L}$ & 3.25 & .46 & $\mathrm{~L}$ & 3.05 & .59 & $\mathrm{~L}$ \\
\hline Industry-Inferiority & 3.07 & .43 & $\mathrm{~L}$ & 3.46 & .45 & $\mathrm{~L}$ & 3.25 & .53 & $\mathrm{~L}$ & 3.05 & .50 & $\mathrm{~L}$ \\
\hline Identity-Role Confusion & 3.23 & .45 & $\mathrm{~L}$ & 3.51 & .44 & $\mathrm{~L}$ & 3.19 & .38 & $\mathrm{~L}$ & 3.04 & .50 & $\mathrm{~L}$ \\
\hline Intimacy-Isolation & 3.30 & .57 & $\mathrm{~L}$ & 3.69 & .46 & $\mathrm{~L}$ & 3.37 & .50 & $\mathrm{~L}$ & 3.15 & .57 & $\mathrm{~L}$ \\
\hline Generativity-Stagnation & 3.40 & .43 & $\mathrm{~L}$ & 3.65 & .37 & $\mathrm{~L}$ & 3.40 & .46 & $\mathrm{~L}$ & 3.23 & .56 & $\mathrm{~L}$ \\
\hline Ego Identity- Despair & 3.20 & .39 & $\mathrm{~L}$ & 3.57 & .35 & $\mathrm{~L}$ & 3.32 & .36 & $\mathrm{~L}$ & 3.18 & .50 & $\mathrm{~L}$ \\
\hline MEPSI & 3.24 & .29 & $\mathrm{~L}$ & 3.55 & .27 & $\mathrm{~L}$ & 3.27 & .34 & $\mathrm{~L}$ & 3.10 & .42 & $\mathrm{~L}$ \\
\hline
\end{tabular}

Legend: $1-2=$ Low score (negative attributes; (if dichotomy low, high) $<3.9=$ low and $>4=$ high; 4-5 =high (positive attributes); MEPSI=Modified Erikson Psychosocial Stage Inventory; $\mathrm{VI}=$ Verbal Interpretation

Table 3 indicates that the seminarians' involvement in the interaction with co-seminarians and in the exploration of their skills through their own initiatives reflects a negative predominant attribute before the administration of PASI. It likewise reveals that the participants manifest low level of confidence in their ability to achieve their goals and industriousness and may have that feeling of inferiority before the intervention was administered to the participants.

A low pretest score on the Identity - Role Confusion scale of the seminarians of both the experimental group (Mean=3.23, $\mathrm{SD}=.45)$ and the control group (Mean=3.19, $\mathrm{SD}=.38$ ) which shows a low level of sense of self and personal identity, wherein their sense of self-reintegration is weak before the administration of the intervention program. This is especially an important one for Erikson (1980), wherein he quoted in his words "the ego values accrued in childhood culminate in what I have called a sense of ego identity. This is the accrued confidence that one's ability to maintain inner sameness and continuity (one's ego in the psychological sense) is matched by the sameness and continuity of one's meaning for others. Thus, self-esteem confirms at the end of each major crisis, grows to be the conviction that one is developing a defined personality within a social reality that one understands".

In the scale of Intimacy-Isolation, pretest scores of the seminarians for both the experimental group (Mean=3.30, $\mathrm{SD}=.57$ ) and control group (Mean=3.37, $\mathrm{SD}=.50$ ) which reported a low level in this attribute and wherein it reveals that the participants have an inferior ability to share 
themselves more intimately to others; fearing commitment and relationship that leads to loneliness before the intervention program was given.

Table 3 also shows a low pretest score for Generativity-Stagnation scale of the seminarians of both the experimental group (Mean=3.40, $\mathrm{SD}=.43$ ) and the control group (Mean=3.40, $\mathrm{SD}=$ .46) which reveals a low level of sense of productivity in work, involvement in community activities and organizations of the seminarians before the intervention program was administered. In the scale of Ego Integrity - Despair, pretest scores of the seminarians for both the experimental group (Mean=3.20, $\mathrm{SD}=.39$ ) and control group (Mean=3.32, $\mathrm{SD}=.36$ ) reported a low level in this attribute and wherein it reveals that the participants have an inferior development of the integrity and wherein they see themselves unsuccessful which can lead them to losing hope, this is prior to the administration of the intervention program.

In the overall psychosocial development scale pretest scores of the seminarians for both the experimental group (Mean=3.24, $\mathrm{SD}=.29$ ) and control group (Mean=3.27, $\mathrm{SD}=.34)$, it is shown that the seminarians had a low level of this attribute revealing that they have an inferior level of psychosocial development before the intervention program was administered.

As presented in Table 3, the posttest scores of the participants in the subscale of Trust-Mistrust of both the experimental group (Mean=3.42, $\mathrm{SD}=.39$ ) shows an increase in the score as compared to the posttest mean score of the control group (Mean=2.93, $\mathrm{SD}=.51$ ) which is low and this signifies that the level of sense of Trust of the experimental group has increased though it still in the low level. The sense of trust of the seminarians in the experimental group is highlighted in their social attributes, which means that their level of confidence in the seminary increased after the PASI program. In the scale of Automy - Shame and Doubt, the posttest score of the experimental group (Mean=3.63, SD .36) shows an increase in the score compared to the posttest mean score of the control group (Mean=3.20, $\mathrm{SD}=.54$ ) which is low and this means that the level of autonomy of the experimental group increased though it is still low and the seminarians were able to assert their independence with an increased self-esteem after the administration of the intervention program.

In the scale of Initiative - Guilt, the posttest mean score of the experimental group (Mean= $3.50, \mathrm{SD}=.35)$ revealed a higher score in comparison to the posttest mean score of the control group (Mean= 3.05, $\mathrm{SD}=.59$ ) which is lower and signifies that the level of Initiative of the experimental group increased but still in a low level. This means that they are able to explore their personal skills through their own initiatives, increasing also their ability in decision making after the PASI. For Industry-Inferiority Scale, the posttest mean score of the experimental group (Mean=3.46, $\mathrm{SD}=.45$ ) shows an increased level of score as compared to the posttest mean score of the control group (Mean=3.05, $\mathrm{SD}=.50$ ) which is low. This means that the level of confidence of the experimental group in their ability to achieve their goals increased and their industriousness also increased, having that feeling of sufficiency after the administration of the intervention program though it is still in a low level of its psychosocial development.

In the Identity - Role Confusion scale. The posttest mean score of the experimental group $(\mathrm{Mean}=3.51, \mathrm{SD}=.44)$ reveals a higher score in comparison to the posttest mean score of the control group (Mean=3.04, $\mathrm{SD}=.50$ ) which is low and this means that the level of sense of self and personal identity of the seminarians of the experimental group through their exploration of beliefs, personal values and goals are increased. Their sense of self-reintegration is strengthened and they are able to commit themselves by being sure of oneself and their place in the seminary. They are also able to establish a positive identity, after the administration of the intervention program. 
Hoare (1991) concluded that a fully achieved identity is one that reflects the individuals' personal cultural values while is still being open to other people of different culture.

In the normative developmental tasks in family life, job life, social life and physical changes areas are promising candidates in explaining this mean-level changes in personality in early adulthood. Although developmental tasks in this life phase mainly refer to life transitions in new social roles, wherein a number of studies now provide empirical evidence to the assumptions made by many scholars as mentioned by Erikson, (1950), Lodi-Smith \& Roberts, (2007 and Roberts \& Wood, (2008) stating that not only the mere exposure to developmental tasks but also the specific experiences in accomplishing these tasks play a role in personality development especially with regard to inter individual differences in change.

In Intimacy-Isolation scale, the posttest mean score of the experimental group (Mean= 3.69, $\mathrm{SD}=.46)$ reveals a higher score in comparison to the posttest mean score of the control group (Mean=3.15, SD=.57) which is lower but is still low in the interpretation and this signifies that the level of the ability of the experimental group to share themselves more intimately to others has increased and they are able to commit themselves leading their relationship to happiness after the intervention program was administered.

For Generativity - Stagnation scale, the posttest mean score of the experimental group (Mean= $3.65, \mathrm{SD}=.37$ ) also shows an increase in score in comparison to the posttest mean score of the control group (Mean=3.23, SD=.56) which is lower and is still in a low level. This means that the level of the sense of productivity in work of the experimental group increased with their involvement in community activities and organizations after the intervention program. In young adulthood, Robert et. al., 2003 stated that the quality to job life seems to play an important role for rank order changes in personality reflected in positive associations between job satisfaction and a decrease in negative emotionality, thus Scollon \& Dinner, 2006 affirmed that it is also as well as an increase in emotional stability and extraversion.

In Ego Integrity - Despair scale, the posttest mean score of the experimental group (Mean= $3.57, \mathrm{SD}=.35$ ) shows an increase in the score in comparison to the posttest mean score of the control group (Mean=3.18, SD=.50) which is lower, manifesting an increase in the level of the development of integrity in experimental group which signifies that the participants were able to see themselves to be successful and that made them hopeful after PASI was administered though the level of their psychosocial development is still low.

In the overall psychosocial development (MEPSI) scale; the posttest mean score of the experimental group (Mean=3.55, $\mathrm{SD}=.27$ ) shows an increase in the score in comparison to the posttest mean score of the control group (Mean=3.10, $\mathrm{SD}=.42)$ which is lower and this signifies an increase in the psychosocial development attributes of the experimental group after the administration of PASI although it is still in the low level of psychosocial development attributes.

O'Hearn \& Gatz, (2002) stated the International empirical research into the promotion of psychological health in children and adolescents has consistently found that following educational interventions children showed better psychological health, negative psychological states were decreased and attitudinal problems prevented. This also affirms Seligman et al., (2014) that quality of life can be improved by the development and application of inner resources that help individuals respond to the different problems and challenges of complicated modern life and an increased problem-solving skill enable individuals to manage stress, difficulties or negative events without becoming frustrated or depressed.

Table 4. Significant Difference between the Pretest and Posttest Psychosocial Development Mean Scores of the seminarians grouped according to experimental and control group 


\begin{tabular}{|l|c|c|c|c|c|c|}
\hline \multirow{2}{*}{ MEPSI SUBSCALE } & \multicolumn{3}{|c|}{$\begin{array}{c}\text { Experimental } \\
\text { Pre and Post }(\mathbf{n = 2 7})\end{array}$} & \multicolumn{3}{c|}{$\begin{array}{c}\text { Control } \\
\text { Pre and Post (n=26) }\end{array}$} \\
\cline { 2 - 7 } & t value & p-value & Decision Ho & t value & p-value & Decision $\mathbf{H}_{\mathbf{o}}$ \\
\hline Trust- Mistrust & 3.03 & .006 & Rejected & 2.11 & .045 & Accepted \\
\hline Autonomy-Shame Doubt & 2.22 & .035 & Rejected & .33 & .742 & Accepted \\
\hline Initiative-Guilt & 3.05 & .005 & Rejected & 2.26 & .033 & Rejected \\
\hline Industry-Inferiority & 3.70 & .001 & Rejected & 2.03 & .053 & Accepted \\
\hline Identity-Role Confusion & 2.73 & .011 & Rejected & 2.38 & .026 & Rejected \\
\hline Intimacy-Isolation & 3.63 & .001 & Rejected & 2.16 & .041 & Rejected \\
\hline Generativity-Isolation & 3.11 & .004 & Rejected & 1.88 & .072 & Accepted \\
\hline Ego Identity-Despair & 5.09 & .000 & Rejected & 1.70 & .102 & Accepted \\
\hline MEPSI & 6.24 & .000 & Rejected & 2.65 & .014 & Rejected \\
\hline
\end{tabular}

Note: Significant if $\mathrm{p}<0.05$

Critical Value $\mathrm{t}=1.96$

df: experimental $=27$; control $=26$

Based from this result, it can be stated that the PASI applied to the experimental group have been effective in enhancing the psychosocial development attributes of the seminarians. As confirmed by Chaing et al. (2015). in their research work on the Effectiveness of a Mind Training and Positive Psychology Program on Coping Skills in School children in Taiwan wherein they said that an effective mind training and positive psychology program may help children and adolescents learn useful coping skills, improve their ability to cope with stress and increase their confidence in facing challenges.

The development of that sense of initiative, ability to lead others and in making decisions made them succeed in their given tasks which helped in the up growth in their third stage of psychosocial development as it increased in its value.

These developmental tasks are associated with mean level changes in development and show that the way people deal with the challenges of developmental tasks are associated with interindividual differences in personality development. Although the specific developmental tasks vary across different life phases wherein this new categorization of tasks could be a useful guide to study personality development in every adult life phase, as Hutteman et al., (2014) ratified. It can be affirmed that the positive affirmation skills and techniques used in the intervention program enhanced a positive change in the thought and behavior patterns of the seminarians. A handful and considerable researches supported the effectiveness of building up the ego development, cognitive- behavior modification through regulation and motivation; self-evaluative reaction to one's self-regulation of action and thoughts. The positive emotions and thoughts to achieve psychological growth helps in building up enduring intellectual, personal, psychological and social means that widen the thoughts of a person, enhancing a desirable or satisfactory well-being. These skills and techniques have been adapted in this research work.

Cognitive restructuring is one of the essential skills/ methods in Cognitive Behavior Therapy which includes identifying and processing negative automatic thoughts, modifying and summoning these negative thoughts (Creed et al., 2011). According to Seligman (1992), acquired positivism and optimism, the fundamental change of the mental process of judgement, reasoning, perception and memory is the one involved in the accountability for putting aside certain knowledge of hopeless and cynical destructive behavior and learning to modify and adjust oneself to a favorable and positive behavior. The behavioral skills and techniques 
embodied stronger ability of the adolescent to act in a particular way with a paradigm shift and positive thought like in relating with others, confidence, assertion of independence self-esteem, in the intervention with co-seminarians and in their decision- making. In collaboration, the ability to achieve one's goals in strengthening identity and self-reintegration, in commitment and emotional relationship, in one's work productivity and in hoping is in the attributes of psychosocial development.

This psychosocial education is the skill and technique that is adapted in the intervention program; learning, education, psychosocial activities, relaxation exercises, expression of ideas, opinions, creative positive affirmation and artwork which was made to help the students develop their psychosocial skills and attributes to effectively increase their positive attribution styles, coping skills and decrease depression, anxiety and internalizing behavioral problems. (Yi-Chen, Chiang et. al., 2015).

Table 5. Significant Difference between the Posttest Psychosocial Development

\begin{tabular}{|l|c|c|c|}
\hline \multicolumn{1}{|c|}{ MEPSI SUBSCALE } & t value & p value & $\begin{array}{c}\text { Decision } \\
\mathbf{H}_{\mathbf{o}}\end{array}$ \\
\hline Trust- Mistrust & 3.885 & .000 & Rejected \\
\hline Autonomy- Shame \& Doubt & 3.443 & .001 & Rejected \\
\hline Initiative- Guilt & 3.318 & .002 & Rejected \\
\hline Industry-Inferiority & 3.139 & .003 & Rejected \\
\hline Identity-Role Confusion & 3.647 & .001 & Rejected \\
\hline Intimacy-Isolation & 3.764 & .000 & Rejected \\
\hline Generativity-Stagnation & 3.179 & .003 & Rejected \\
\hline Ego Identity-Despair & 3.303 & .002 & Rejected \\
\hline MEPSI & 4.656 & .000 & Rejected \\
\hline
\end{tabular}

Note: *Significant if $\mathrm{p}<0.05$

Critical Value $\mathrm{t}=1.96$

This implies that the null hypothesis that there is no significant difference between the posttest psychosocial development mean scores of the experimental and control group is rejected. This result indicates that the intervention program of the PASI was effective. This means that there was an incremental increase in scores after exposure in the intervention of PASI. The participants in the experimental group experienced not only an enhancement of their psychosocial development attributes but it went beyond enhancing - it facilitated the growth of their psychosocial development attributes which means that experimental group had a high level of psychological understanding of self or self-depth as compared to the control group, making an impact on their psychosocial development characteristics and attributes.

The importance of positive emotions that stems from Fredrickson (1998), which suggests that positive emotions, although experienced briefly can create a long term beneficial changes. Positive emotions create a momentary openness to new thoughts and behaviors that can become long term resources, which in turn can create more positive emotions thereby facilitating an escalating growth cycle. The client's momentary positive emotions can lead to creativity, openness to change and development of resources. (Fredrickson \& Branigan, 2005)

Table 6. Measure of Effect Size of the Positive Affirmation Skills Intervention on the Psychosocial Development of the Seminarians

\begin{tabular}{|c|c|c|}
\hline Groupings & r & Interpretation \\
\hline Experimental Group & 1.30 & Lage Effect \\
\hline
\end{tabular}


Table 6 showed the effect of the Positive Affirmation Skills Intervention on the Psychosocial development of the seminarians. The effect size estimate which is $r=1.30$ is considered a large effect. Since in Cohen's guide for interpretation 0 to 0.20 has small effect, 0.20 to 0.50 has medium effect and 0.50 and up has a large effect. This signifies that there was a large effect on the psychosocial development attributes of the participants in the experimental group compared to the control group, thus confirming that the Independent variable which is the Positive Affirmation Skills Intervention was effective in causing a change in the dependent variable which is the Psychosocial Development attributes of the participants further supporting Fredrickson \& Branigan (2005), mentioning that positive Affect increases individual's attention and motivation, thereby leading to improve coping and problem solving wherein this improvement in coping, in turn, is likely to have a positive impact on the person's well-being.

It is also pertinent to highlight an in-depth study to explore the Positive Affirmation Skills Intervention on the Psychosocial Development of the seminarians to enhance and improve the intervention program. Selecting participants from different settings like in the urban areas to see the effectiveness of the PASI program since the study is limited only to the seminarians from a rural area which is a small population, it is considered to include a large population including big seminaries and communities.

The incidence of low psychosocial development attributes of the seminarians can give lead for an identification of psychosocial problems among the candidates for priestly life which could reduce poor quality of psychosocial development of seminarians. Future research can be done to help identify psychosocial problems in different perspectives and aid in the enhancement of the psychosocial skills and development of the seminarians. PASI can be integrated in the formation program of the seminarians in order to deal with the psychosocial issues of the seminarians and develop their mental health and psychosocial skills. However, a longitudinal research can be applied to know the strength and effectivity of the newly developed intervention program that was used in the current study.

\section{Conclusion}

The Positive Affirmation Skills Intervention (PASI) program was developed by the researcher and validated through expert evaluation, pilot study and experimental study. The results showed Positive Affirmation Skills Intervention (PASI) program proves to be an efficacious tool for enhancing the level of the psychosocial development attributes of the seminarians. The experimental study results revealed that there is no significant difference between the pretest scores of the experimental group and the control group in terms of the psychosocial development attributes before participating in the Positive Affirmation Skills Intervention (PASI) program. However, in the posttest scores showed a significant difference in the experimental group, whereas the control group remained low. This indicates the Positive Affirmation Skills Intervention (PASI) was effective in enhancing the psychosocial development attributes of the seminarians of the experimental group. It made an impact on the psychosocial development growth of the seminarians in the experimental group. The extent of the effectiveness of the Positive Affirmation Skills Intervention (PASI) program revealed. The large effect of the program on the psychosocial development subscales and proves that it is an effective tool in enhancing the psychosocial development attributes of the seminarians.

\section{References}

Chaing, Y., Shih, H., Lin, D., \& Lee, C. (2015). Effectiveness of a mind training and positive psychology program on coping skills in schoolchildren in Taiwan. $J$ of Child and Adolescent Behavior, 3(5), 246-253. 
Creed, T. A., Reisweber, J., \& Beck, A. T. (2011). Cognitive therapy for adolescents in school settings. Guilford Press.

Erikson, E. H. (1980). Identity and the life cycle: A reissue New York : Norton

Erikson, E. H. (1993). Childhood and society. WW Norton \& Company.

Fredrickson, B. L. (1998). What good are positive emotions?. Review of general psychology, 2(3), 300-319.

Fredrickson, B. L., \& Branigan, C. (2005). Positive emotions broaden the scope of attention and thought-action repertoires. Cognition \& emotion, 19(3), 313-332.

Goleman, D. (2013). Focus: The Hidden Driver of Excellence, A\&C Black. Business \& Economics, 320(8).

Harms, P. D. (2008). One or many? An experimental study of power and personality in autocratic and democratic groups. University of Illinois at Urbana-Champaign.

Hoare, C. H. (1991). Psychosocial identity development and cultural others. Journal of Counseling \& Development, 70(1), 45-53.

Hutteman, R., Hennecke, M., Orth, U., Reitz, A. K., \& Specht, J. (2014). Developmental tasks as a framework to study personality development in adulthood and old age. European Journal of Personality, 28(3), 267-278.

Kang, S. K., Galinsky, A. D., Kray, L. J., \& Shirako, A. (2015). Power affects performance when the pressure is on: Evidence for low-power threat and high-power lift. Personality and Social Psychology Bulletin, 41(5), 726-735.

L. Fredrickson, B., \& Levenson, R. W. (1998). Positive emotions speed recovery from the cardiovascular sequelae of negative emotions. Cognition \& emotion, 12(2), 191-220.

Lodi-Smith, J., \& Roberts, B. W. (2007). Social investment and personality: A meta-analysis of the relationship of personality traits to investment in work, family, religion, and volunteerism. Personality and social psychology review, 11(1), 68-86.

Neyer, F. J., \& Lehnart, J. (2007). Relationships matter in personality development: Evidence from an 8-year longitudinal study across young adulthood. Journal of personality, 75(3), 535-568.

O'Hearn, T. C., \& Gatz, M. (2002). Going for the Goal: Improving youths' problem-solving skills through a school-based intervention. Journal of Community psychology, 30(3), 281-303.

Parker, P. D., Lüdtke, O., Trautwein, U., \& Roberts, B. W. (2012). Personality and relationship quality during the transition from high school to early adulthood. Journal of personality, 80(4), 1061-1089.

Roberts, B. W., \& DelVecchio, W. F. (2000). The rank-order consistency of personality traits from childhood to old age: a quantitative review of longitudinal studies. Psychological bulletin, 126(1), 3 .

Roberts, B. W., Wood, D., \& Caspi, A. (2008). The development of personality traits in adulthood.

Scollon, C. N., \& Diener, E. (2006). Love, work, and changes in extraversion and neuroticism over time. Journal of personality and social psychology, 91(6), 1152. 
Seligman, M. E. P. (1992). Helplessness: On depression, development, and death (Reprint ed.). New York: Freemen

Seligman, M. E., \& Csikszentmihalyi, M. (2014). Positive psychology: An introduction. In Flow and the foundations of positive psychology (pp. 279-298). Springer, Dordrecht.

Zimmermann, J., \& Neyer, F. J. (2013). Do we become a different person when hitting the road? Personality development of sojourners. Journal of personality and social psychology, 105(3), 515. 